\title{
New Data on Seawater Intrusion in Liepāja (Latvia) and Methodology for Establishing Background Levels and Threshold Values in Groundwater Body at Risk F5
}

\author{
I. Retike ${ }^{1,2}$, J. Bikše ${ }^{1}$ \\ ${ }^{1}$ Faculty of Geography and Earth Sciences, University of Latvia, Riga, Latvia \\ ${ }^{2}$ Hydrogeology division, Latvian Environment, Geology and Meteorology Centre, Riga, \\ Latvia
}

\begin{abstract}
Intensive water consumption in former decades caused formation of large depression cone near city Liepāja and resulted with seawater intrusion into Upper Devonian Mūru-Žagaru confined freshwater aquifer. Area affected by seawater intrusion is delineated as separate groundwater body at risk (F5) and according to Groundwater Directive threshold values for groundwater bodies at risk must be established to assess the status of a body and identify possible trends. Correct estimation of background levels is significant for determination of threshold values. This study shows an updated so called "BRIDGE" methodology for determination of background levels. A two-step approach how to establish background levels in much stricter manner is presented. Also, data on major ion chemistry, biogenic and trace elements in groundwater and seawater from sampling campaign in 2017 are displayed. Dataset include unique seawater sample taken from Baltic Sea. Finally, the calculated seawater fraction results in groundwater samples shows up to $50 \%$ presence of seawater which decrease with increasing distance from the coast and increasing screen interval.
\end{abstract}

\section{INTRODUCTION}

Groundwater body is a management unit established by Water Framework Directive (WFD 2000). Good chemical status of groundwater body shall be based on compliance to existing Community quality standards and on threshold values (TV) to be established by Member States at the most appropriate level (local, regional or national) (Marandi and Karro 2008).

TV must be established for all pollutants and indicators of pollution which characterized groundwater bodies as being at risk of failing to achieve good groundwater chemical status in accordance with WFD (2000). Regarding saline concentrations resulting from human activities, Member States may decide to establish TV values either for sulphate and chloride or for conductivity (GWD 2006).

The determination of TV should be based on several aspects including hydrogeological characteristics and information on background levels (BL) (GDW 2000). Normally BL are estimated following so called "BRIDGE methodology" (Müller et al. 2006). Methodology proposes approach for derivation of TV which includes application of both natural BL and environmental quality standards (Urresti-Estala et al. 2013).

The aim of this study was to develop and present updated methodological approach for determination of BL and TV for groundwater body at risk F5- seawater intrusion in Liepāja (Latvia). As well the results from sampling campaign (year 2017) are presented demonstrating data on major ion chemistry, biogenic and trace elements taken from 
monitoring wells and Baltic Sea. Finally, the results from survey were used to calculate the proportion of seawater fraction (\%) in groundwater.

\section{METHODS}

\section{Materials and data preprocessing}

Information about monitoring and abstraction wells and springs was gathered from the largest Latvian hydrogeological database "Wells" (limited access) (Urbumi 2017). Data about major ion chemistry $\left(\mathrm{Ca}, \mathrm{Mg}, \mathrm{Na}, \mathrm{K}, \mathrm{Cl}, \mathrm{SO}_{4}, \mathrm{HCO}_{3}\right)$ and nitrates $\left(\mathrm{NO}_{3}\right)$ were extracted and limited to: (1) the area of groundwater body F1 part of which is the area affected by seawater intrusion (F5) and (2) to aquifers of interest - Upper Devonian Mūru-Žagaru ( $\left.\mathrm{D}_{3} m r-\check{g} g\right)$.

BRIDGE methodology (Müller et al. 2006) suggests a list of minimum criteria which should be used to avoid usage of anthropogenically influenced samples (Marandi and Karro 2008). Data preprocessing included: (1) removal of historical samples which reported sodium and potassium as a sum (NaK) (an additional criterion); (2) removal of samples with ionic balances error greater than $\pm 10 \%$ as suggested by Müller et al. (2006) and (3) where such information was available samples with nitrate content exceeding $4 \mathrm{mg} / \mathrm{l}$ were removed as potentially affected by human activities. Much stricter criterion than suggested $10 \mathrm{mg} / \mathrm{l}$ by Müller et al. 2006 was chosen based on most recent study about geochemical composition of groundwater in Latvia (Retike et al. 2016).

\section{Determination of background levels}

BL for chloride ion was calculated in two steps to minimize the error of visual identification of the inflection point. Firstly, freshwater samples were separated from seawater affected samples - the value of the inflection point on groundwater samples was detected by applying probability plots (Panno et al. 2006). According to BRIDGE methodology samples with $\mathrm{NaCl}>1000 \mathrm{mg} / \mathrm{l}$ should be removed. Much stricter criteria were used, and value of the inflection point for chloride was set $18 \mathrm{mg} / \mathrm{l}$. Results were compared with values obtained by Retike et al. (2016). Next, BL for chloride ion was determined as $90^{\text {th }}$ percentile of all freshwater samples below the inflection point value according to BRIDGE methodology (Müller et al. 2006). This step was accomplished for two reasons: (1) the validation results from previous study suggested that $18 \mathrm{mg} / \mathrm{l}$ for chloride might be too high (Retike et al. 2016) and (2) visual observation of the inflection point is subjective and may hold some uncertainty. Similarly, BL were set for sulphate and sodium.

\section{Calculation of threshold values}

TV for chloride, sulphate and sodium were calculated according to BRIDGE methodology (Müller et al. 2006) which suggests deriving TV on the basis of the ratio between the estimated BL and relevant reference value (REF). In this case $\mathrm{BL}<\mathrm{REF}$, therefore Equation 1 was used.

$$
\mathrm{TV}=(\mathrm{REF}+\mathrm{BL}) / 2
$$

Drinking water standard from Latvian legislation (CR No-671 2017) was chosen as REF, respectively $250 \mathrm{mg} / 1$ for chloride and sulphate, and $200 \mathrm{mg} / \mathrm{l}$ for sodium. 


\section{Sampling campaign}

Groundwater samples were collected from 9 monitoring wells during sampling campaign accomplished from 08.06.2017 till 19.06.2017. Samples were taken by the staff of Latvian Environment, Geology and Meteorology Centre (LEGMC) responsible for national groundwater monitoring. Groundwater samples were taken according to LVS ISO 566711:2011 standard. Sample from Baltic Sea aquatory was taken in 11.05.2017 by the stuff of Latvian Institute of Aquatic Ecology. The seawater sampling area and depth $(9 \mathrm{~m})$ was chosen based on existing knowledge about possible area where seawater intrudes freshwater aquifers. All samples were analyzed in LEGMC laboratory which is accredited according to the standard LVS EN ISO/IEC 17025.

Concentrations of $\mathrm{Ca}, \mathrm{Na}, \mathrm{K}$ and $\mathrm{Mg}$ were determined by inductively coupled plasma optical emission spectrometry; $\mathrm{SO}_{4}, \mathrm{Cl}$ and $\mathrm{Br}$ by ion chromatography; $\mathrm{NO}_{3}$ and $\mathrm{NH}_{4}$ by segmented flow analysis; As by atomic absorption spectroscopy; $\mathrm{HCO}_{3}$ by titration; TOC by catalytic oxidation; $\mathrm{P}_{\text {tot }}$ by persulphate digestion, molybdenum blue colorimetry. Sampling methods are in accordance with the procedure laid down in Article 21 of WFD (2000) and meet the requirements of the European Commission "Guidance on Groundwater Monitoring" (European Commission 2007).

\section{Calculations of seawater fraction}

Seawater fractions $f_{\text {sea }}$ in groundwater samples were calculated based on both chloride and bromide ions as conservative tracers (Appelo and Postma 2005) by Equation 1:

$$
f_{\text {sea }}=\frac{m_{X(\text { sample })}-m_{X(\text { freshwater })}}{m_{X(\text { seawater })}-m_{X(\text { freshwater })}} \times 100 \%
$$

where $m_{X}-$ concentration of either chloride or bromide concentration in either freshwater, seawater or groundwater sample. Chloride concentration for freshwater sample $(3.4 \mathrm{mg} / \mathrm{l})$ was calculated as average chloride value from samples taken from wells No.9322 and No.2254. These wells are inland background monitoring stations for $\mathrm{D}_{3} m r-\check{z} g$ aquifer (samples not affected by seawater intrusion). Sample taken from Baltic Sea represented overall seawater chemical composition.

\section{RESULTS}

\section{Background levels and threshold values}

Final BL for chloride was set as $13.2 \mathrm{mg} / 1$, for sulphate $42.5 \mathrm{mg} / 1$ and for sodium $22.3 \mathrm{mg} / 1$. Calculated TV for chloride, sulphate and sodium was respectively $131.6 \mathrm{mg} / 1,146.3 \mathrm{mg} / \mathrm{l}$ and $111.2 \mathrm{mg} / \mathrm{l}$. TV values are officially introduced in national level by an order of the Minister (Order-257 2016).

\section{New data on seawater intrusion}

Results from sapling campaign are presented in Table 1. Ionic balance for 6 samples (5 groundwater and 1 seawater) was in range from $-0.3 \%$ till $6.9 \%$. For three samples sodium was removed due to erroneous values derived from laboratory. All nitrates were under detection limit $(0.091 \mathrm{mg} / \mathrm{l})$. 
Table 1. Results for major ion chemistry of groundwater samples taken from Upper Devonian Mūru-Žagaru aquifer and Baltic Sea.

\begin{tabular}{|c|c|c|c|c|c|c|c|c|c|c|}
\hline \multirow{2}{*}{$\begin{array}{l}\text { Sample } \\
\text { No }\end{array}$} & \multicolumn{2}{|c|}{$\begin{array}{l}\text { Coordinates } \\
\text { (LKS-92) }\end{array}$} & \multirow{2}{*}{$\begin{array}{c}\begin{array}{c}\text { Screen } \\
\text { interval }\end{array} \\
\mathrm{m}\end{array}$} & $\mathrm{Ca}$ & Mg & $\mathbf{N a}$ & $\mathbf{K}$ & $\mathrm{HCO}_{3}$ & Cl & $\mathrm{SO}_{4}$ \\
\hline & $\bar{X}$ & $\mathrm{Y}$ & & \multicolumn{7}{|c|}{$\mathrm{mg} / \mathrm{l}$} \\
\hline 862 & 316954 & 270095 & $40-50$ & 186 & 77 & 45.7 & 17.3 & 151 & 87 & 534 \\
\hline 2642 & 316749 & 267688 & $47-57$ & 221 & 107 & - & 41 & 224 & 1270 & 186.3 \\
\hline 2645 & 316398 & 268166 & $72-77$ & 57.4 & 31.2 & 24.8 & 11.8 & 267 & 8.6 & 63 \\
\hline 2647 & 316425 & 268173 & $45-58$ & 240 & 129 & - & 47 & 213 & 1800 & 203 \\
\hline 9322 & 379051 & 279726 & $38-52$ & 74 & 24.3 & 5.1 & 5.2 & 340 & 3.08 & 10 \\
\hline 2254 & 405437 & 302631 & $40-47$ & 101 & 22.8 & 4.65 & 1.59 & 420 & 3.71 & 0.03 \\
\hline 8849 & 318470 & 266461 & $54-67$ & 63 & 32.8 & 21 & 12.3 & 370 & 9.1 & 16 \\
\hline 8850 & 317574 & 267496 & $51-66$ & 134 & 67.8 & - & 24.7 & 276 & 435 & 78 \\
\hline 8851 & 318105 & 267105 & $51-65$ & 68 & 35.4 & 30.8 & 14.2 & 310 & 62.1 & 31 \\
\hline $\begin{array}{c}\text { Baltic } \\
\text { Sea } \\
\text { sample }\end{array}$ & 31 & 27 & 9 & 94 & 286 & 2400 & 70 & 107 & 4100 & 537 \\
\hline
\end{tabular}

Table 2. Results for in situ measurements, biogenic and trace elements of groundwater samples taken from Upper Devonian Mūru-Žagaru aquifer and Baltic Sea.

\begin{tabular}{|c|c|c|c|c|c|c|c|c|c|}
\hline \multirow{2}{*}{$\begin{array}{c}\text { Sample } \\
\text { No }\end{array}$} & $\mathbf{p H}$ & $\mathbf{E C}$ & $\mathbf{T}$ & $\mathbf{F e}_{\text {tot }}$ & $\mathbf{B r}$ & $\mathbf{A s}$ & $\mathbf{P}_{\text {tot }}$ & $\mathbf{N H}_{\mathbf{4}}$ & $\mathbf{T O C}$ \\
\hline & & $\begin{array}{c}\boldsymbol{\mu} \mathrm{S} / \mathrm{cm} \\
\left(20^{\circ} \mathrm{C}\right)\end{array}$ & ${ }^{\circ} \mathrm{C}$ & \multicolumn{5}{|c|}{$\mathrm{mg} / 1$} & $\mathrm{mg} \mathrm{C} / 1$ \\
\hline 862 & 7.65 & 685 & 10.4 & 1.45 & 0.31 & 1.19 & $0.006^{*}$ & 0.24 & 0.19 \\
\hline 2642 & 7.6 & 3747 & 9.6 & 1.06 & 0.38 & $0.2^{*}$ & 0.011 & 0.6 & 1.27 \\
\hline 2645 & 7.95 & 587 & 9.8 & 0.85 & $0.05^{*}$ & 3.4 & 0.098 & 0.3 & 0.71 \\
\hline 2647 & 7.57 & 6971 & 10.4 & 1.12 & 6.1 & $0.2^{*}$ & 0.013 & 0.73 & 1.6 \\
\hline 9322 & 7.67 & 234 & 7.9 & 1.66 & $0.05^{*}$ & 1.69 & 0.027 & 0.22 & 1.19 \\
\hline 2254 & 7.52 & 360 & 7.4 & 2.13 & $0.05^{*}$ & $0.2^{*}$ & 0.037 & 0.13 & 7.7 \\
\hline 8849 & 7.63 & 367 & 10.2 & 0.44 & $0.05^{*}$ & $0.2^{*}$ & $0.004^{*}$ & 0.27 & 1.38 \\
\hline 8850 & 7.64 & 1593 & 10.1 & 0.83 & 1.33 & $0.2^{*}$ & 0.006 & 0.44 & 1.37 \\
\hline 8851 & 7.75 & 495 & 10 & 0.86 & 0.19 & $0.2^{*}$ & 0.007 & 0.3 & 0.95 \\
\hline $\begin{array}{c}\text { Baltic } \\
\text { Sea } \\
\text { sample }\end{array}$ & - & 13300 & 5.86 & 0.02 & 12.2 & 0.92 & 0.024 & 0.042 & 4.4 \\
\hline
\end{tabular}

*under detection limit

\section{Seawater fraction in groundwater samples}

Seawater fraction in groundwater samples from $\mathrm{D}_{3} m r-z ̌ g$ aquifer was calculated based on chloride and bromide ions as conservative tracers. Calculation by both tracers yield comparable results for less mineralized groundwater, however, more saline groundwater samples from wells No.2647 and No.2642 yield different results (Figure 1).

Seawater fraction reaches $50 \%$ in groundwater sample at the central part of seawater affected zone (distance from coastline about $1.3 \mathrm{~km}$ ). The seawater fraction significantly decreases with increasing distance from coastline- at $3.4 \mathrm{~km}$ from the coastline the fraction is only $1 \%$ (well No.8851). Wells No.2647 and 2645 are both representing the same aquifer and located in the same area (one station), about $1.3 \mathrm{~km}$ from the coastline- but they have different screen intervals (Table 1). Well No.2647 with shallower screen interval shows seawater fraction up to $50 \%$, but the well No.2645 with deeper screen interval reflects no seawater 
presence. The cause for such difference is more than $6 \mathrm{~m}$ thick clay layer separating $\mathrm{D}_{3} m r-z ̌ g$ upper part from lower part of the aquifer.

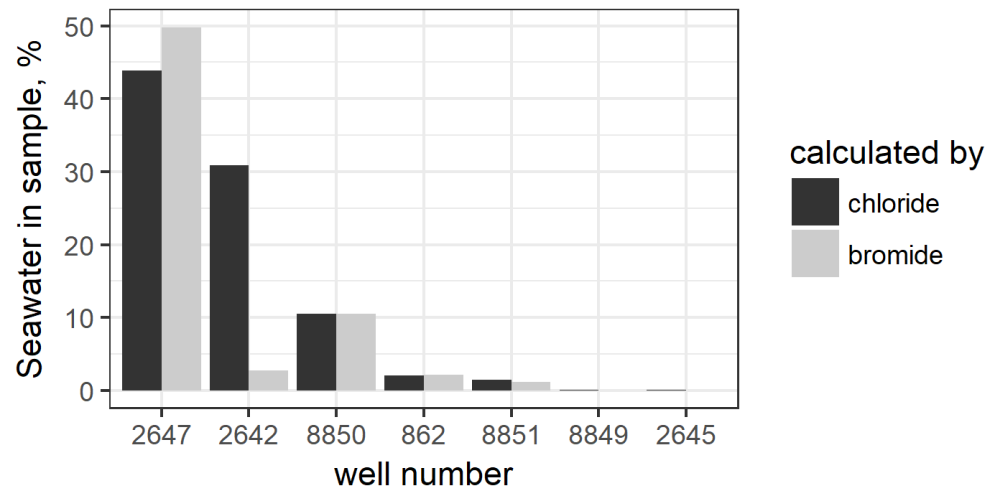

Figure 1. Seawater fractions in groundwater samples from $D_{3} m r-\check{g} g$ aquifer.

\section{DISCUSSION AND CONCLUSIONS}

Up to $50 \%$ of groundwater in study area consists of seawater. Such high seawater fraction was promoted by continuous groundwater abstraction from the $\mathrm{D}_{3} m r-z ̌ g$ aquifer. Seawater fraction decreases with increasing distance from coastline as well as with increasing depth.

Background levels established by two-step approach are strict and accounts for worst case scenario. Such approach yields lower threshold values therefore it is more sensitive to water quality changes and it takes more time to reach good chemical status. However, this leads to more sustainable water management in coastal areas where groundwater resources are limited.

\section{ACKNOWLEDGEMENT}

The study was supported by performance-based funding of University of Latvia Nr.AAP2016/B041//ZD2016/AZ03 within the "Climate change and sustainable use of natural resources" programme.

\section{REFERENCES}

Appelo C.A.J, Postma D. 2005. Geochemistry, Groundwater and Pollution, second ed. A.A. Balkema Publishers.

CR No-671 2017. Ministru kabineta 2017. gada 14. novembra noteikumi Nr. 671 "Dzeramā ūdens obligātās nekaitīguma un kvalitātes prasības, monitoringa un kontroles kārtība" (Cabinet Regulation No 671 of 14 November 2017 "Mandatory Harmlessness and Quality Requirements for Drinking Water, and the Procedures for Monitoring and Control thereof" (In Latvian).

European Commission 2007. Guidance Document No. 15: Guidance on Groundwater Monitoring. European Communities, Luxembourg.

GWD 2006. Directive 2006/118/EC of the European parliament and of the Council of 12 December 2006 on the protection of groundwater against pollution and deterioration. 
Marandi, A. and Karro, E. 2008. Natural background levels and threshold values of monitored parameters in the Cambrian-Vendian groundwater body, Estonia. Environmental Geology. 54: $1217-$ 1225 .

Müller, D., Blum, A., Hart, A., Hookey, J., Kunkel, R., Scheidleder, A., Tomlin, C., Wendland, F. 2006. Final proposal for a methodology to set up groundwater threshold values in Europe, Deliverable D18, BRIDGE project.

Order-257 2016. Order 257 on limit of values for pollutants and their groups in groundwater bodies at risk (03.10.2016). The Minister of Ministry of Environmental Protection and Regional Development of the Republic of Latvia.

Panno, S.V., Kelly, W.R., Martinsek, A.T., Hackley, K.C. 2006. Estimating background and threshold nitrate concentrations using probability graphs. Ground Water, 44: 697-709.

Retike, I., Kalvans, A., Popovs, K., Bikse, J., Babre, A., Delina, A. 2016. Geochemical classification of groundwater using Multivariate statistical analysis in Latvia. Hydrology Research, 47: 799-813.

Urbumi 2017. Derīgo izrakteņu atradņu reǵistrs (Register of Mineral Resources). Latvian Environment, Geology and Meteorology Centre. Available from: https://www.meteo.lv (In Latvian).

Urresti-Estala, B., Carrasco-Cantos, F., Vadillo-Pérez, I., Jiménez-Gavilán, P. 2013. Determination of background levels on water quality of groundwater bodies: A methodological proposal applied to a Mediterranean River basin (Guadalhorce River, Málaga, southern Spain. Journal of Environmental Management, 117: 121-130.

WFD 2000. Directive 2000/60/EC of the European parliament and of the Council Establishing a Framework for Community Action in the Field of Water Policy.

Contact Information: I.Retike, University of Latvia, Faculty of Geography and Earth Sciences, Jelgavas Street 1, LV-1004, Riga, Latvia, Email: inga.retike@lu.lv 